\title{
[報 告
}

\section{浦川土 石 流 調 査}

榎本 正雄 榎本 真 中島 樹

\section{General introduction on rocky mudflow investigation at Urakawa}
by Masao Enomoto*, Makoto Enomot* and Akira Nakajima*

\begin{abstract}
In the designated district to the Matsumoto Sabo Construction Work Office, Ministry of Construction, there are many mountain streams having been troubled by the rucky mudflow damages.

To investigate the cause of the rocky mudflow, many experiments together with the actual prevention works for the rocky mudflow have been done by the members belonged to this office.

This report introduces briefly the general view of the organization and methods on the rucky mudflow investigation in our office.
\end{abstract}

\section{1. 調查の概要}

土石流に対する調査が現在までに不十分であった原 因は，土石流の発生か山間地で，豪雨時に突発的に起 こること，また土石流の発生する素因，誘因が複雑に からみ合っていることにある。

松本砂防工事事務所の管内には，工事施工河川で姫 川支流浦川，焼岳火山を侵食する上堀沢という土石流 の発生頻度のきわめて高い溪流がある。そこで, 松本 砂防ではこの土石流の発生頻度が高く, 調査対象河川 として好条件を備えている。姫川支流浦川に执いて46 年度より土石流の調查を開始した。

本報告はこの土石流調査の状況を紹介するもので, 調查は流動する土石流の解明を主体とし, 発生機構, 堆積機構, 構造物に対する影響, 対策方法の解明を目 的としているものである。

\section{2. 調查地の概要}

調查地は姫川左支浦川流域（長野県北安量郡小谷村 浦川地先）図-1 で実施している。

調査地は写真 (写-1) により知られるごとく, 明治 44 年稗田山を中心に発生した崩壊土量 $150,000,000 \mathrm{~m}^{3}$ の大崩壊の堆積土砂を侵食する金山沢と浦川本川を対 象としている。このうち, 金山沢はこの大崩壊地を侵

* 建設省 松本砂防工事々務所

* Matsumoto Sabo Construction Work Office, Ministry of Construction.
食する幼年期の侵食溪流である。調查地域は，金山沢 上流部を土石流発生地域，下流 $1.2 \mathrm{~km}$ ，浦川本川出 口までが流下地域，浦川本川より浦川堤までの約 $1 \mathrm{~km}$ が堆積区間と推定されるのでこの各区間を調査の対象 地域とした。

地形条件は, 金山沢の河床勾配が $1 / 8.4$, 河床幅 $5 \sim$ $6 \mathrm{~m}$, 崖高 $30 \sim 80 \mathrm{~m}$ のV字谷であり, 豪雨, 融雪期に は斜面より供給の土砂が河床に堆積する。また本川は 河床勾配 $1 / 12$ で河床幅が $60 \sim 80 \mathrm{~m}$ と急に広くなって 浦川堤まで続いている。(図-2)

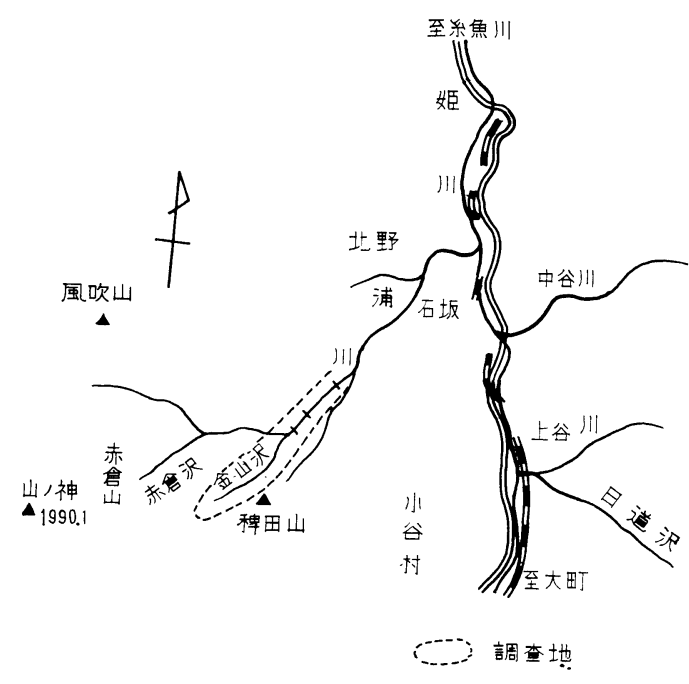

図- 1 浦川土石流調査位置図 


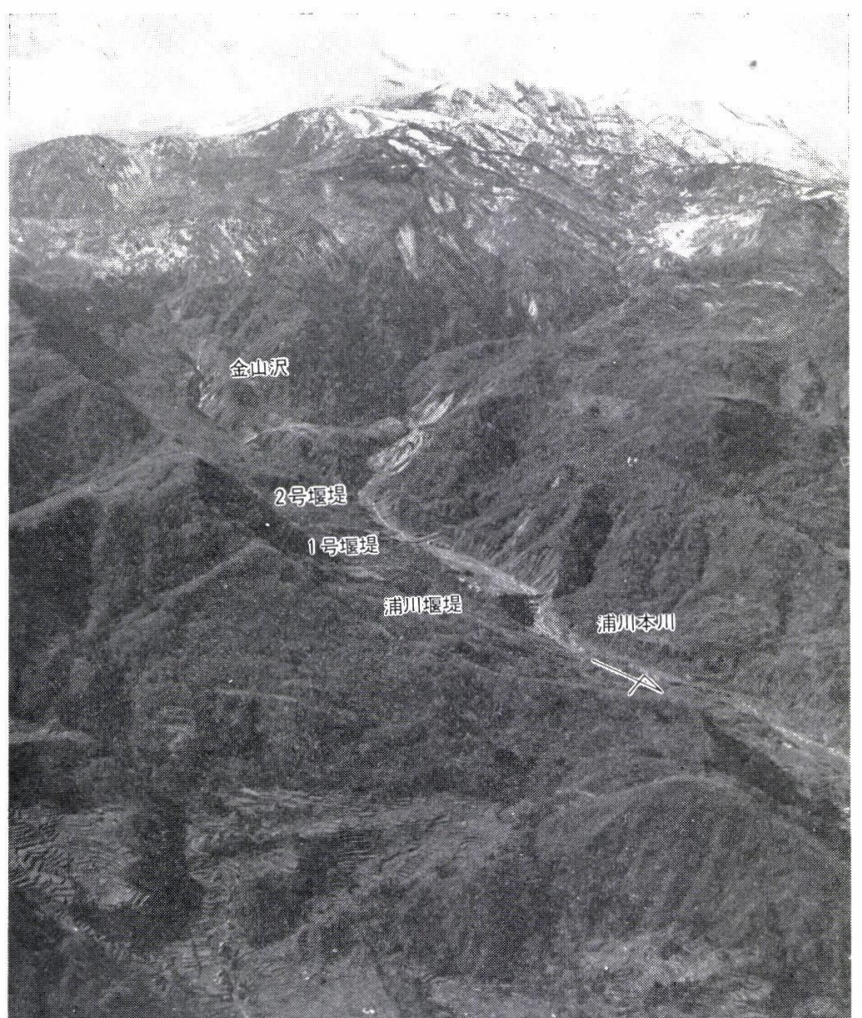

写真-1 姫川水系・浦川（昭和46年11月撮影）

浦川は1911年の稗田山の大崩壊によって土石流に上る谷の埋稓が扢こなわれ, をの後急速な侵食の復活によって河床低下, 下流部姫川の河床上昇と急速な地 形変化を行なっている。

\section{3. 調查の概要}

調査内容求よび調查の流れは表-1 のフローチャー トに示した如くである。

発生機構調査; 雨量観澌 (普通雨量計, 雨量強度計)

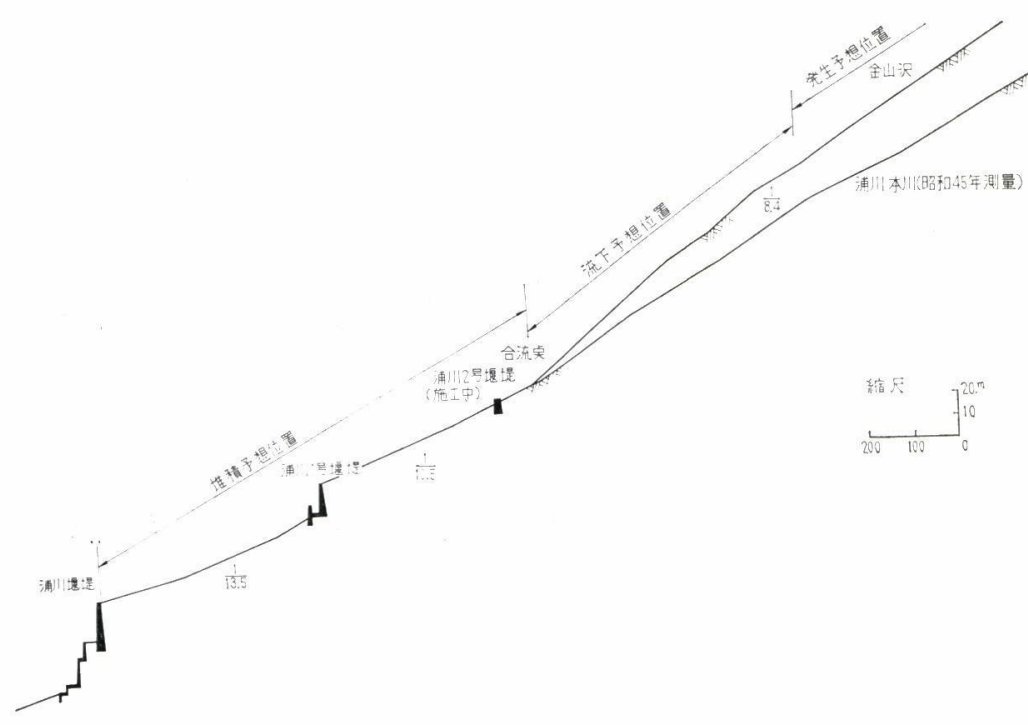

図-2 浦川土石流観測地

䄑式縦断図
を実施し,加えて地形地質調査， 土質試験，河床堆積厚調查を実 施する。

流動状況調查; 流動観測はVTR(ビデ オカメラを主として，シネカメ ラ）索設置し，流動状況を観察 する。突発的に起こる土石流に 対処するため全自動化にしてい る。流速 (土石流の速さ), 水位 (土石流先端頭) 測定は検知線に よって自動的に測定している。 また土石流の物理特性は採泥筒 によって土眇を採取し発生後分 析する。

嫶積機構調查 (土石流発生後調査); 堆 積位置の地形的特徴, 粒度分布 堆積形状, 堆積土量, 痕跡調查 を実施する。

構造物に対する影響調査; 土石流の衝 撃力と衝撃によってダム内部に 働く応力の測定を笑施する。こ のため衝撃力の測定のため圧痕 式荷重計を設置する。

\section{4. 調査の詳細}

\section{4-1 土石流の発生機構調査}

1. 土質, 地質調査

金山沢上流部発生地域の土質, 地質調査を高精度て 行なう。また, 発生地域の地質, 地質構造を明らかにす ると同時に, 発生点付近は, 地すべり性崩壊地带であ るので,地下水の流動状況， クラック状況等を調查す る。金山沢谷頭は粘土や粘 土化した土で構成されて抢 り降雨，地下水による含水 比変化が土質特性に影響を 与え土石流発生に密接に関 係する。このため発生地域 の多数個所た土の採取を行 ない土質試験支行なう。[粒 度分布コンシステンシー (液性限界塑性限界) 透水試 験, 含水比変化による力学 特性の変化等了来実施する。

（2）発生位置の確認

現地に木杭を打ち这み， 土石流発生後の調査によっ 
て, 発生位置の確認を行な う。また, 発生位置の規模 の推定を行なう。

\section{4-2 土石流の流動状況}

調查

1. VTR, $8 \mathrm{~mm}$ 流動状 沉観察シネカメラを設置し て流動状況を親察する。観 測地点は図-3 に示す如く, 流下地带と推定される金山 沢中流部の金谷橋と，本川 筋の第 1 号堰堤右岸（堆積 地域にを設置した。(写-2 参照)

この VTRは最上流部に 設置したNo. 1 の検知線が 切れると作動する構造とな っており，図一 4 に示すよ うにビデオモニターテレ ビ，ビデオコーダーで記録 を開始する。それと同時に親測小屋のブザーがなり， 土石流の発生を知らせる。この段階から人間により調 整卓でカメうの切り替之や、りモコン操作器によりモ

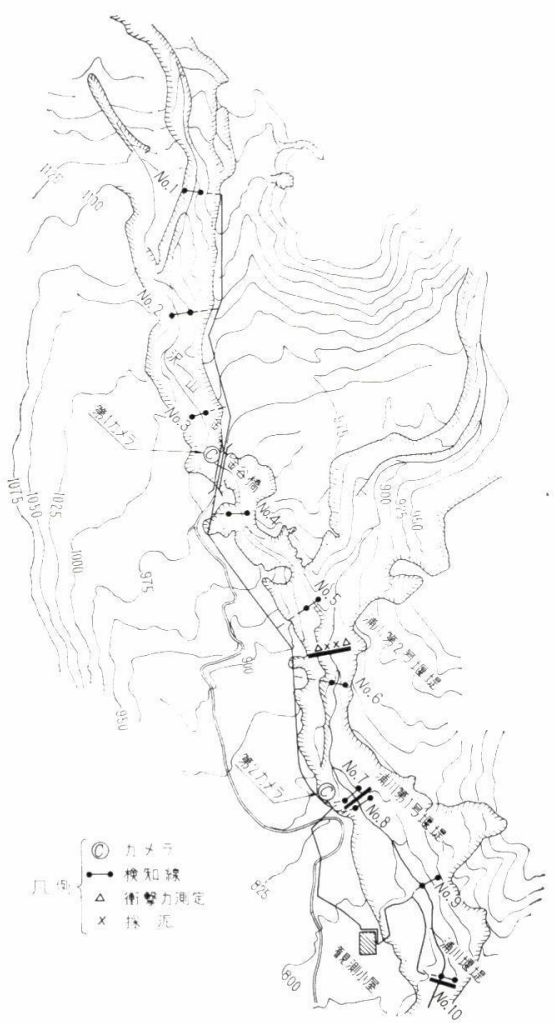

図-3＼cjkstart浦川土石流調查設備

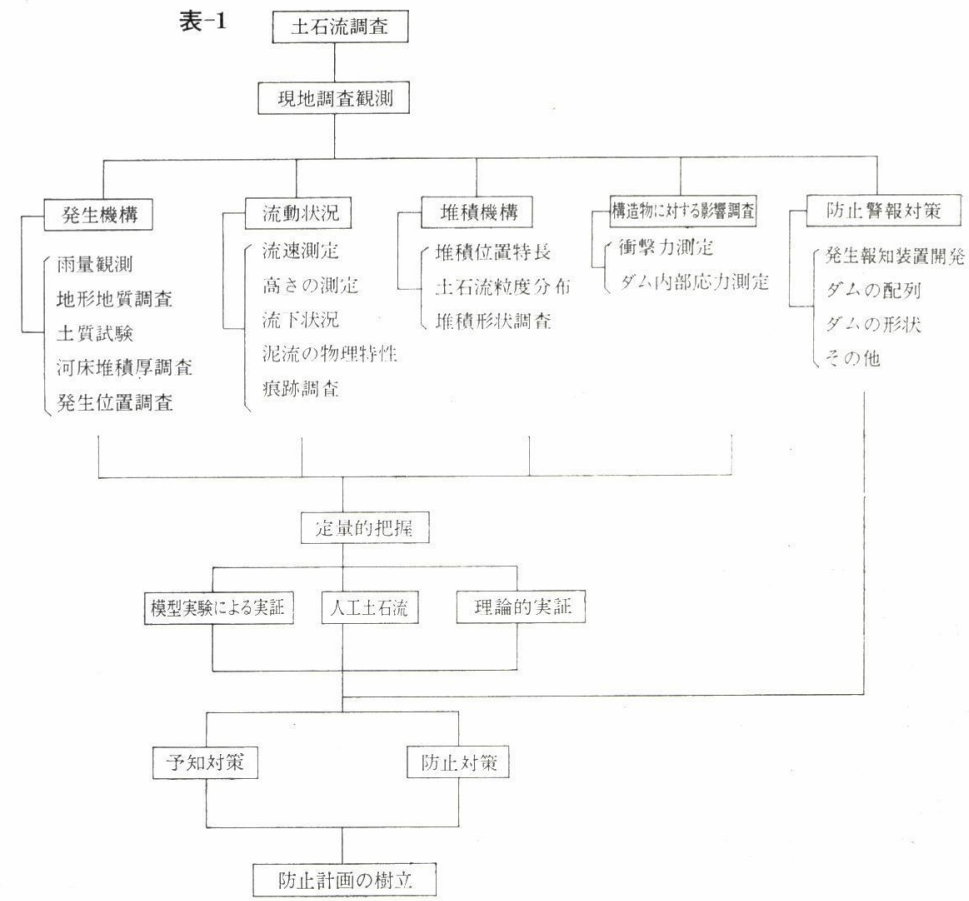

ニターを見ながら土石流の追跡を行なう。夜間の記 録，霧等要条件時については，今後解決してゆきた い。

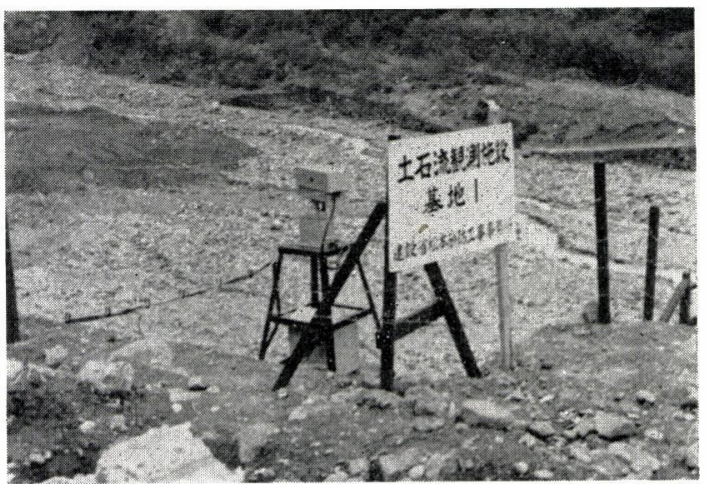

写真-2 カメラ設置状況 1 号堰堤右岸に設置し たVTR $\left(\begin{array}{c}\text { 堆皘地域と推定 } \\ さ れ る と こ ろ ~\end{array}\right)$ 


\section{2. 流速および高さ測定}

流動状況観測装置と一体になっており，土石流の通 過によって検知線 が切れると，図一 5 に示すように切 れた検知線番号と, 日, 時, 分, 秒がデジタルコーダ 一に印刷される。これにより 9 ケ所の平均流速が計算 される。なお落石等のための切断は, 位置が印刷され るのて容易に発見される。検知線高さの決定には過去 の土石流発生時の水位を参考にし，本川 $0.5 \mathrm{~m}$, 金山 沢 $0.8 \mathrm{~m}$ としている。（写-4参照）土石流頭観測は今 後の課題であるが，検知線を横断方向に高さを変えて 数段設置して測定することを計画している。

3. 土石流の物理特性

土石流は比較的細かい土砂と共に巨大な磂が一体と なって流動する。この巨大な石を動かす原動力が，多 量の粘土を含む泥流であるといわれている。この物理 特性を調査するため採泥設備を 図- 6 に示すように堰 堤の袖部採泥円筒を設置して実施している。土石流通 過後採取し, 比重, 粒度分布等を分析する。また, こ れにより水通断面通過の土石流の高さの概略を知るこ ともできる。

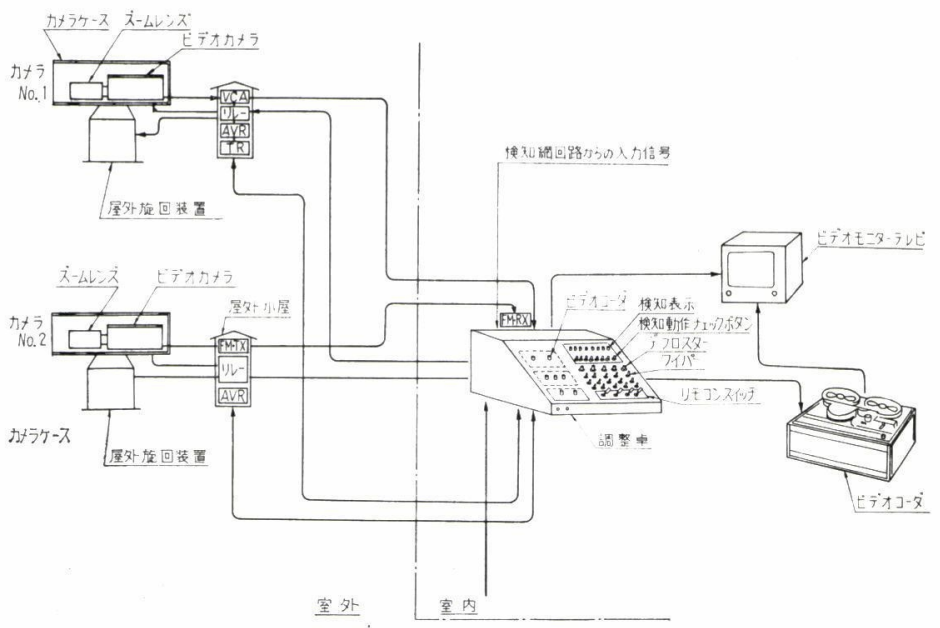

図-4 土石流監視装置系統図

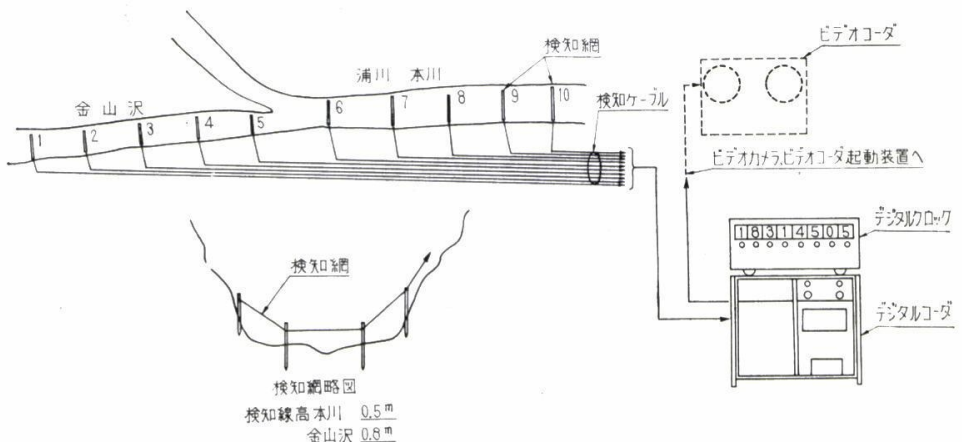

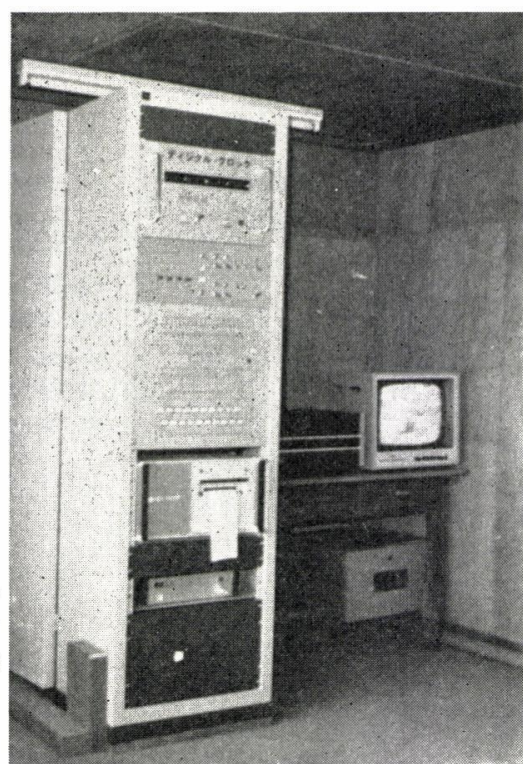

写真-3 室内制御装置全景

\section{4-3 土石流の堆積機構}

建設省指定課題「土石流に関す る研究」調査実施要領に従う。

\section{4-4 構造物に対する影響}

ダムに対する衝撃力の測定を行 なう。衝撃力はなだれの衝撃測定 に用いる圧痕式荷重計を採用し，

図- 7 に示す如く 1 号堰堤に設置 し，最大衝撃力を測定している。 圧痕式荷重計は, アルミ板, 鉄板 等をコーンの背面に設置して拉 ，土石流通過後に，アルミ板につ いたコーンの痕跡により衝撃力の 推定を行なうものである。これに より衝撃力の大きさが明らかにな れば荷重計等を用い連続記録を行 なう予定である。

\section{4-5 防止及び警報対策の検討}

土石流の防止工法の検討は， 1 . 堰堤の有無による効果の差異。 2 . ダム群設置の検討（発生地域, 流 下地域, 堆積地域等のどの位置の 設置が最も効果的か)。3. ダム形 状の検討。4. 土石流発生時の警報 を出すための警報装置の開発等て ある。 


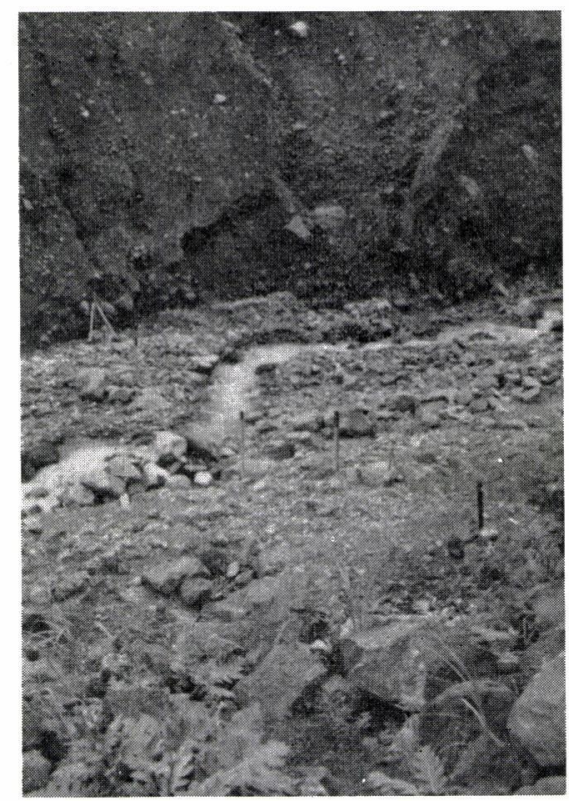

写真-4 検知線設置状況

\section{5. あとがき}

土石流の解明は遅々として進んで打らず，な かんずくこの土石流の挙動を見た人さえすくな く, “まぼろしの土石流”とさえ言われている。 松本砂防ではこの問題に対処するため昭和 46 年度より土石流調查に取り組んでいる。

本報告はこの土石流を解明するための調查を 浦川観測地を中心に紹介したものである。なお， 管内には土石流多発溪流として燅岳を侵食する 4 本の溪流があり，この溪流のうち上堀沢については 京都大学防災研究所と共同調査を行なっている。この 種の調查方法, 観測体制については今後どのような方 法が最も良いか暗中模索の状況であり，また，観測設 備についても開発はこれからの状況である。

今後, これらの諸問題を各々解決してこの調查を成 功させたい。そのためには土石流の発生を自然に待つ
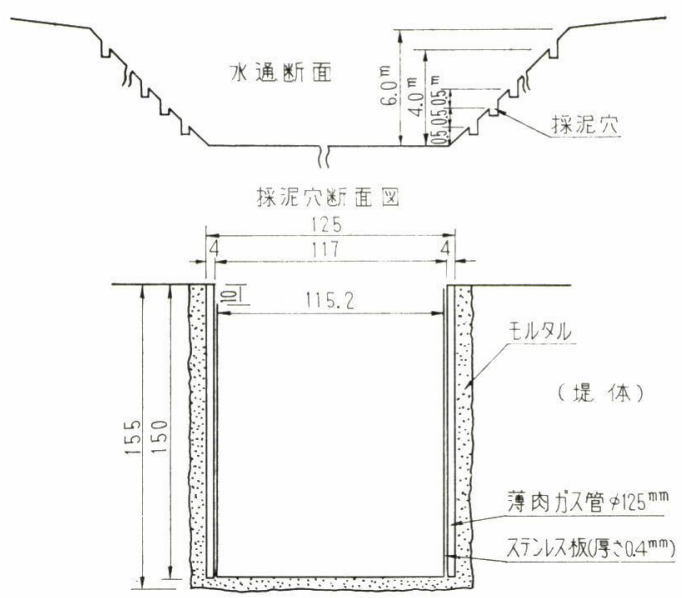

图- 採泥器設置位置および構造

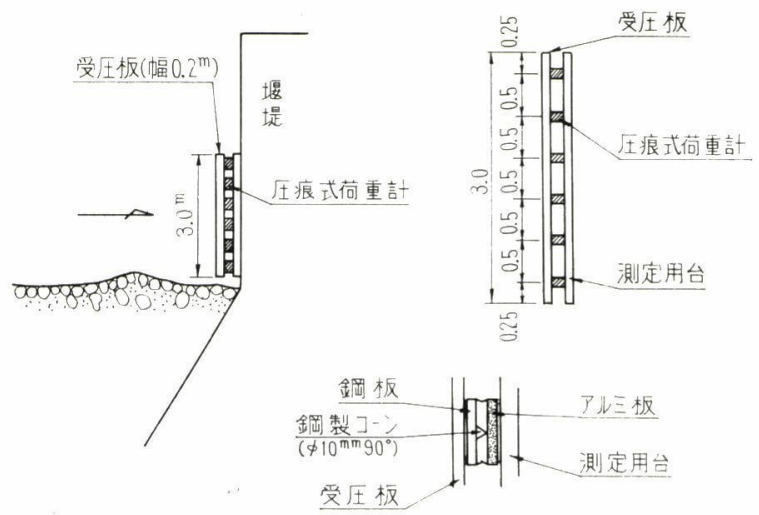

図-7 衝撃力測定装置

より人工的に土石流を発生させ、これによって諸測定 を行ならことが最効果的と考えているが，これらの 点についても今後皆様の御指導を打願いする次第で す。

最後に本調查の施設を始め, 諸事項について, 京都 大学防災研究所の指導を得ていることを報告し, 御指 導に感謝するものであります。 


\section{土石流調査における写真測量の利用}

1 急激な地形変化を行なっている土石流発生地 带の地形変化在航空写真により定量的に把握す る。

2 土石流流下状態を立体カメラにより前面，側 面より撮影し，土石流の形状を把握し，体積計 算を行ない土石流の規模を推定する。

3 コマドリ写真により水位を一定間隔で測定す る。

4 巨碩の移動（流下）状況を写真により把握す る。

\section{説 明}

1 松本砂防事務所管内て最为崩壊が激しく, 急 激な地形変化老行なっている溪流は，信濃川水 系に打いては焼岳の四支溪, 姫川水系では, 浦 川が上げられる。この2 渓流においては隔年で 航空写真支撮影し, 地形変化上り崩壊土砂量を 算出し，砂防計画上て役立てている。

浦川撮影年月日 $33,37,40,46$ 年
焼岳
39，41，46年

2 土石流流下量を直接的に測定することは困難 であるので間接的になるが立体カメラを用い， 一定間隔で測定することが考学られる。しかし 現段階に打いては，気象条件の悪い山岳地带で 連続的に精度老高く撮影することが，金銭的に 高くなり, 現場への利用は, 現時点では不可能 に近い状態であるので，これらの開発が望まれ る。（焼岳において昭和 46 年度防災研が一枚撮 りで実施)

3 砂防関係の一般分野に打いても水位, 流量観 測は最も困難な技であり，どこの事務所に抢い ても苦労していることが多い一般河川関係と同 様土石流の水深を測定することは不可能であり 新しい測定方法の開発をしなければならない。

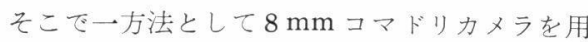
い，間接的に一定間隔で量水板を読みとる方法 が考えられる。

4 土石流発生後, 現地において上くみられるこ とは，巨㭗が下流まで流れついて打り常識では 考光られない事が多い。また発生の前期から木 期まで一連の挙動をとらえられ，これらに対処 するにはカメラ等在用い連続撮影によるのが最 为良い方法であると考学る。
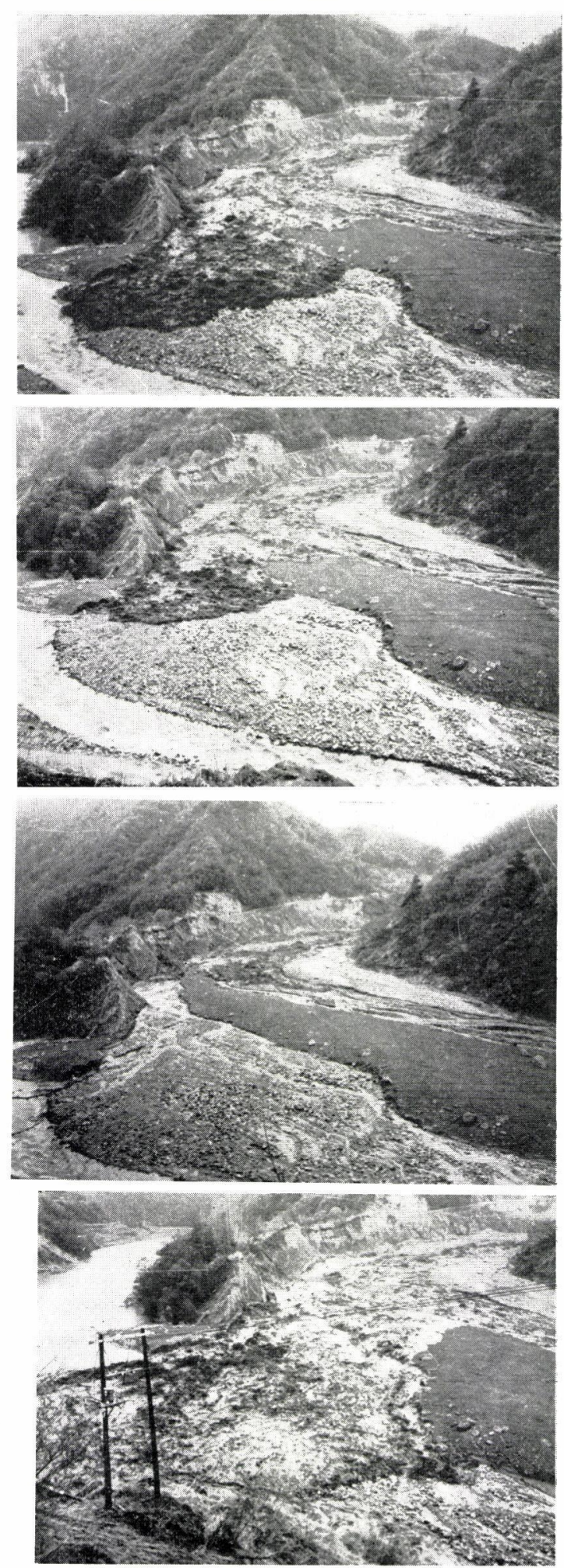

写真説明：浦川では昭和 39 年 40年の 2 年間で大土石流は36回発生し ている。写真は39年 5 月 12 日発生のもので姫川本川右岸から浦川支川を 撮ったもの，3〜4秒おきに撮している。（相模組提供） 